\title{
DETERMINING THE EMBEDDEDNESS OF SUSTAINABILITY CLAIMS IN STRATEGISING: A COMPARATIVE STUDY OF THE ALSI 40 COMPANIES
}

\author{
Marius Pretorius - Dept. of Business Management, University of Pretoria, South Africa. \\ Catherine le Roux - M Com Candidate, Dept. of Business Management, University of Pretoria.
}

Purpose: To determine the level of sustainability embeddedness in strategising by investigating the public and external communication of companies.

Problem investigated: The extent to which sustainability is embedded in the elements of strategy formulation and implementation (and not merely surface-level statements and claims)

Design: The researchers designed a measurement tool and scale, the Strategising for Sustainability Index (SSI), based on researched elements of strategising and recent literature on the topic of sustainability and strategy integration. Merit for strategising for sustainability was given to a company on the basis of its fulfilling the relevant criteria. The JSE Top 40 listed companies on the All Share Index as of March 2011 were selected as a purposive sample. Each company's data and each element of the scorecard were judged on a Likert-type five-point scale, with higher scores indicating higher levels of embeddedness in the strategy. A comprehensive evaluation sheet was used to judge the presented data individually and independently for each element of the scorecard instrument.

Findings: Ten elements were found relevant and represented: compliance (2 elements); strategy formulation (4 elements); and strategy implementation (4 elements). The findings show wide variation in overall scores. Almost all companies satisfied the compliance requirements but variations were observed in both formulation and implementation embeddedness. The SSI tool has discrimination value despite a relatively complex judging process. The proposed SSI measurement challenges other determinants of sustainability performance, as it incorporates embeddedness of sustainability in strategising. Knowing the level of this could guide management towards directing resources away from 'over-invested' strengths related to sustainability. Considering the scores for the different elements of the instrument would help to prioritise the 'sustainability spend'. Furthermore, the SSI tool directs attention to how sustainability is incorporated in the strategising process.

Originality and Value: The measure of the level of embeddedness of sustainability in strategising has not been done before. This study addresses the possible 'window-dressing' claims surrounding sustainability and highlights those companies who have successfully demonstrated that sustainability is not just for reputation purposes and is, in fact, part of their operating as a listed company.

Conclusion: Firstly, it was possible to use the SSI framework and the evaluation process and apply it to the sustainability reporting and claims for each firm. Secondly, each element could be judged on the unique scale for the specific element. The SSI measurement tool can be used to describe the level of strategising embeddedness. The SSI tool's framework is based on input of literature and on the foundation of strategic principles. The 5-point scale on the SSI tool serves to describe the achievement of a company for each element. The sustainability claims of these companies varied in embeddedness in the process of strategising. The score is lower for the formulation elements, raising the question of whether some projects are possibly implemented ad hoc to score points, without being necessarily formulated as part of strategy.

Key words: Sustainability, Strategising, Measurement, Communication

\section{INTRODUCTION}

'For the first time, there's a global understanding, if not a feeling of urgency that sustainability, in every possible meaning of the word, is the only way forward' (Trendwatching, 2010).

In a single month in 2010, South Africa passed 47 amendments and extensions to its sustainability legislation and regulation, ranging from chemical management to atmospheric emissions to fertilisers and everything in between. Compliance may be a means of response by organisations; however, in 


\section{Pretorius \\ C. le Roux}

Determining the embeddedness of sustainability claims in strategising: a comparative study of the ALSI 40 companies

terms of sustainability; they have to do more than just 'embrace the notion of being a good corporate citizen' (Laszlo \& Zhexembayeva, 2011:18).

To truly prosper, corporate leaders need to 'move with the culture' (Trendwatching, 2010; Laszlo \& Zhexembayeva, 2011:18). A recent study found that nine out of ten consumers around the world say they are ready to switch to companies offering products and services that help to reduce carbon emissions, while two out of three are willing to pay (on average) eleven percent more for them (Lacy, Arnott \& Lowitt, 2009:485). Similar findings by the National Consumers League and Fleishman-Hillard survey of United States (US) consumers reported the social responsibility of a company as being the number one determining factor in brand loyalty (Laszlo \& Zhexembayeva, 2011:18).

Sustainability, the new media and business buzzword, yields 28 million results when a Google search of the term is conducted. This suggests that sustainability is more than just a trend and that it is creating a permanent shift in the very nature of business (Crews, 2010:15; Bonn \& Fisher, 2011:5).

The business case for sustainability, rather than ethics and philosophy, proposes that sustainability is an unavoidable reality for businesses. This can be attributed to rising consumer and investor pressure deriving from publicity about unsustainable business and the detrimental consequences thereof, such as the BP oil spill (Hillestad, Xie \& Haugland, 2010:441; Hallstedt, Ny, Robèrt \& Broman, 2010:703; The Guardian, 2010). In fact, it has been suggested that sustainability is vital for companies to survive and thrive (Adams \& Frost, 2008:289). Simply put: whether sustainability is an act of leadership or a desperate reaction to the pressures of NGOs, consumer trends and activist voters, governments are taking social and environmental issues to heart, adding new laws and regulations to the pressures shaping the business environment. The question is: 'Will your company ride the wave of legislative changes to get ahead of the curve, or wait until the waters drag it under?' (Laszlo \& Zhexembayeva, 2011:24).

The question surrounding sustainability is no longer a matter of 'Should we accommodate it?' Instead, given its connection to the financial bottom line and its role of governance, the question has become: how to do so.

Sustainability has been said to be the 'missing ingredient in strategy', which supports the notion of sustainability 'embeddedness' in strategising (Bonn \& Fisher, 2011:5). Embedded sustainability is a company's response to a radically different market reality and business dimension, one that unifies the profit, ecological and social spheres in a single integrated value-creation space (Laszlo \& Zhexembayeva, 2011:2). Collins, Lawrence, Pavlovich \& Ryan (2007:729) argue that a 'prerequisite for all sustainability' is a strategy. The conception that there is a complementary relationship between strategising and sustainability is supported by several authors (Lacy et al., 2009:484; White, 2009:386; Hallstedt et al., 2010:703). Each of these stresses that a proper understanding of the relationship between strategy and sustainability is crucial in gaining a sustainable competitive advantage in the twenty-first century.

Those advocating for the integration of sustainability in strategising propose various models, suggestions and tools for leaders in their role of strategising (Lacy et al.,2009:489; Reilly, 2009:33; Quinn \& Dalton, 2009:21; Searcy, 2009:50; Leon-Soriana, Munoz-Tirress \& Chalmeta-Rosalen, 2010:249; Holton, Glass \& Price, 2010:152. Crews, 2010:17; Elmualim, Shockley, Valle, Ludlow \& Shah, 2010:58; Bonn \& Fisher, 2011:6).

Despite the powerful forces for corporate sustainability - including global pressure, informed leadership, available tools and frameworks, and its connection to business performance - the embeddedness of sustainability may be impeded by equally strong forces against its implementation (Klaine \& Von Hauff, 2009:520; Reilly, 2009:33; Hillestad et al., 2010:440). Strategising for sustainability is not a trivial task (Holton et al., 2010:152). There is consensus among leaders that while the 'case for change is made' the goal is both 'complex' and 'elusive' (Crews, 2010:17; Elmualim et al., 2010:58). 
Simultaneously, research indicates a significant rise in the use of corporate websites for reporting sustainability activities of companies attempting to acknowledge and respond to changing local/national and global societal expectations concerning business practices (Lee, Fairhurst \& Wesley, 2009:141). It was found that 68 percent of the Top 250 Global Fortune 500 companies embraced sustainability reporting (Gill, Dickinson \& Scharl, 2008:244). It is also not a surprise that transparency was chosen as the cover topic of the April 2010 issue of the Harvard Business Review (Laszlo \& Zhexembayeva, 2011:2)..

The increase in expectation and monitoring of websites by stakeholders necessitates a consistent and transparent communication strategy (Rolland \& Bazzoni, 2009:249; Laszlo \& Zhexembayeva, 2011:14). Companies who want to harness the benefits of sustainability, secure and assure stakeholders and protect their reputation have turned to their most public and global form of communication: their websites (Coupland, 2005:256; Bowers, 2010:250).

The external communication strategies of companies have been identified as an area of concern. It appears that some sustainability claims are not integrated in strategising and are only surface level. Hillestad et al. (2010:441) have determined that eighty percent of the Fortune 100 flaunt their values publicly - values that too often stand for nothing but wanting to be politically correct. These authors propose that reporting has become an 'exercise in compliance' which contributes little to learning or innovation in companies. In fact, sustainability reports have been said to provide little evidence showing how businesses attend to environmental and social issues and their direct enhancement of/impact on the economic performance of business (Bowers, 2010:250).

There is little research investigating the degree to which companies detail sustainability initiatives publicly or strategically (Lee et al., 2009:141). Investigations that have been conducted into the websites of companies have focused on the frequency and level of sustainability claims, language use, themes and the adoption of sustainability into mission and value statements (Coupland, 2005:356; Capriotti \& Moreno, 2007:221; Adams \& Frost, 2008:288; Bowers, 2010:249). Other research has evaluated the presence of corporate responsibility on corporate web pages, conducted content analyses and made comparisons between old and new reports to identify the shift to sustainability (Uusi-Rauva \& Nurkka, 2010:300). Research focus areas, however, have not provided much insight into the process of strategy formulation and implementation for sustainability, or the embeddedness of sustainability claims. This is in spite of the genre of the sustainability report, which has been criticised from both inside and outside corporate walls (Bowers, 2010:250).

The JSE SRI Index has a set of criteria to measure those companies listed on the JSE that integrate the principles of the Triple Bottom Line (TBL) and good governance into their business activities. The process is to target the top 40 companies by market capitalisation on the JSE and then research and scrutinise their most recent publicly available material such as annual reports, company websites and other sources and then give feedback to the preliminary profiles of the companies for the completion of surveys when necessary and for the companies to clarify research and gather non-public information. The criteria for measurement are predetermined core indicators that cover elements that companies should have as a minimum, as well as desirable indicators that are aspirational or advanced (JSE, 2011). While also a form of sustainability measurement on the way in which companies detail sustainability initiatives (TBL), the measurement of embeddedness of sustainability in strategising elements is not the focus. The core criteria do not directly measure the level of sustainability in strategising elements, and the process is subject to the influences of marketing and self-evaluation and reputation biases, especially when the survey is supplied to companies in the sample for their input.

The 'well justified' and supported case for strategising for sustainability (Leon-Soriana et al., 2010:249), accompanied by models and tools for embedding sustainability, has provided leadership and management with the 'how to', yet embedding sustainability into strategising remains a complex task and there are challenges in its implementation (Crews, 2010:17; Elmualim et al., 2010:58). 
Concerns about the legitimacy of claims and the lack of implementation have been expressed amidst a genre of increased reporting and enhanced communication strategies. Companies have been proclaiming the degree to which sustainability forms part of their operations and their achievement of sustainability goals. Yet reporting and corporate websites have also been a source of criticism (Bowers, 2010:250). According to a recent study, twenty-three percent of US consumers say they have 'no way of knowing' if a product is green or if it actually does what it claims. This points to a gap between stakeholders' levels of confidence and the marketing claims on corporate websites (Laszlo \& Zhexembayeva, 2011:15).

The implementation gap between what is said and what is done is the justification for further study on this topic. A gap exists, in that leaders experience challenges in embedding sustainability into strategising, yet there has been an increase in intensity of sustainability reporting and claims. Reports and claims on communication platforms such as websites are considered by some to be only surfacelevel in nature (Riccaboni \& Leone, 2010:130). Motivation to explore this gap is spurred by the Legitimacy Theory, which argues that an organisation's relationship with society can be built through communication and disclosure between that organisation, government and individuals (Coupland, 2005:356; Cowan, Dopart, Ferracini et al., 2010:525). These points framed the research question of this research as: What is the status of strategising for sustainability amongst the JSE ALSI Top 40? Is there evidence that sustainability is embedded into strategising? (Table 1).

\section{Key focus of the study}

Communicating sustainability through external and public communication has acquired increasing importance because it is considered to be an activity that legitimises an organisation in the eyes of society (Capriotti \& Moreno, 2007:221). This research attempts to determine the level of sustainability embeddedness in strategising so as to answer the following questions: What is the strategising for sustainability status of the Top 40 JSE listed companies? For that a measurement tool needs to be designed, leading to: What can the proposed Strategising for Sustainability Index (SSI) tool describe and reveal about the level of embedded sustainability in the strategising of companies? Key to this article is therefore the proposed tool for measurement and whether it could deliver valid measurements that could discriminate between companies and reveal strategising gaps.

\section{Background to the study}

Sustainability has become a boardroom-level strategic business issue. However, according to business leaders themselves, the skills, awareness and knowledge of executives are inadequate to meet this challenge. The radical transformation required cannot possibly be driven by environmental managers hidden away in their environmental silos (Kane, 2011).

Strategising is the process by which business leaders formulate and implement strategies to achieve the goals of the organisation and, hopefully, sustained competitive advantage (Hodgkinson \& Clarke 2007:243). New trends, new taxes and new business dimensions are foreseen or reacted to by navigating the path that the business will follow by means of a strategy. Those companies who can identify the opportunities and risks stand to perform best among competitors dealing with the market change.

Before proceeding, it is critical to define the key constructs which are also the units of analysis, namely sustainability, sustainability claims, and strategising, in order to guide the literature study and the development of the proposed measurement tool.

Sustainability: creates long-term shareholder value by taking up opportunities and managing associated risks that derive from TBL (economic, environmental and social) developments (Crews, 2010:15; Elmualim et al., 2010:59). It is often mentioned in association with responsible leadership, the use of resources and corporate social responsibility.

Sustainability claims: are distinctive remarks, marketing labels and brands, developed by public and private sector institutions (UNCTAD, 2011) about sustainability achievements and projects. They are 
generally communicated through websites, public documents and with products and services. They attest that the company itself, its products and supply chains incorporate the pillars of sustainability (economic, social and environmental).

Strategising: is the process of formulating and implementing a strategy (Hodgkinson \& Clarke 2007:243). The interest of strategising is how initiatives are approached and resources applied to eventually achieve competitive advantage.

The next section explores the context in which the search for 'sustainability embeddedness' is sought and provides a working definition of it, as used in this text.

\section{Context for delineation of sustainability embeddedness in strategising}

The sustainability imperative: is shaping the business landscape and will continue to do so (Lacy et al., 2009:492). In a globalising world, corporate involvement in the elements of sustainability is both necessary and expected (Skinner \& Mersham, 2008:239). Lee et al. (2009:2) note that sustainability is neither a 'passing trend' nor an 'optional addition' for organisations. Sustainability is in fact a buzzword and has been a significant topic for climate change conferences, governments and Non Governmental Organisations (NGOs) in recent decades (Crews, 2010:15), and also at conferences on management, leadership, ethics, philosophy and more. External forces, including stakeholders such as governments, customers and communities, place pressure on businesses to adopt sustainable practices. Although previously shifted to the Corporate Social Responsibility (CSR) division by companies, in current times the topic warrants greater consideration and attention (Lacy et al., 2009:484).

Ideally, companies should feel compelled to act in a socially, environmentally and financially responsible manner at all times because of ethical obligations that are either internally or externally motivated (Lee et al., 2009:2). Companies are also encouraged to strive for sustainability and, in striving towards such a goal, enjoy success in the financial, social and environmental spheres (Skinner \& Mersham, 2008:239). The reality, however, is that irrespective of whether one accepts or rejects the sustainability or CSR premise or its implementation, the concept merits business people's attention for its bottom-line implications (Idemudia, 2011:1; Lee et al., 2009:2). In fact, the case for change has been successfully made and the need to balance the TBL in business is apparent (Elmualim et al., 2010:58).

The business case for sustainability, rather than ethics and philosophy, proposes that sustainability is an unavoidable reality for businesses as consumer and investor pressures rise with the knowledge of climate change and other social needs (Hillestad et al., 2010:440; Hallstedt et al., 2010:703). The TBL case suggests that all elements of sustainability should be adopted and integrated by businesses, as it 'makes good economic sense' (Collins et al., 2007:729).

The bottom-line motivators for a shift to sustainability (Uusi-Rauva \& Nurkka, 2009:300; Smith \& Sharicz, 2011:73) are known as the drivers or benefits. These include cost savings (Uusi-Rauva \& Nurkka, 2009:300), the attraction of talented job applicants, and employee pride and support for the firm's vision and values (Lacy et al., 2009:485). Sustainability is associated with innovation, such as in the process of designing products and services that are more sustainable and welcomed by the newly sensitive market. Companies also stand to enjoy a positive reputation and brand from disclosing sustainable initiatives. Collins et al. (2007:730) relate that in a survey, seventy percent of CEOs said that reputation and brand had considerable or extensive impact on motivation and approach to sustainability. These drivers contribute to enhanced revenue, making significant strides towards competitive advantage (Cowan et al., 2010:525).

Strategy theory: identifies strategy as the coordinated means by which an organisation pursues its goals and objectives (Carpenter \& Sanders, 2009:35). Leaders identify risks and opportunities from internal and external sources and include an analysis of the industry and the macro environment. Strategy formulation, the process of deciding what to do, involves the formulation of vision, mission, 


\section{Pretorius \\ C. le Roux}

setting of goals and objectives and determining of sources of competitive advantage (Lynch, 2009:490). Strategy implementation, the process of performing all the activities necessary to do what has been planned, encompasses formulating action plans, aligning organisational structure, setting systems and measures and rewards in place to achieve the firm's goals and objectives (Lynch, 2009:490; Carpenter \& Sanders, 2009:35). Together, strategy formulation and implementation make the process of strategising (Hodgkinson \& Clarke, 2007:243).

Strategising can be achieved through a prescriptive or an emergent approach (Lynch, 2009:6). The prescriptive approach to strategising involves deliberate planning by the firm, it is one where the objective has been defined in advance and the main elements have been developed before strategy commences (Lynch, 2009:37). Leaders are expected to devise thoughtful, informed and deliberate decisions that will lead to achieving organisational goals. The leader is expected to 'know the way and show the way and go the way' (Crews, 2010:18).

The emergent approach, on the other hand, strives towards an objective which is often unclear and whose elements are developed during the course of the strategising process. It suits fast-developing markets as it considers the dynamic changes in the environment and adjusts to accommodate them, offering flexibility. Leaders are guided by strategic intent and the outcome is unknown (Lynch, 2009:225).

Strategising for sustainability: addresses the alignment of sustainability initiatives with short- and long-term business decisions and falls within the body of knowledge of strategy. Embedded sustainability is not just a better environmentalist strategy; it is a company's response to a radically different market reality and business dimension, one that unifies the profit, ecological and social spheres in a single integrated value-creation space (Laszlo \& Zhexembayeva, 2011:2). The King III report emphasised that 'Strategy, risk, performance and sustainability have become inseparable' and this entails integrated reporting by companies (Ince.motiv., 2010).

Most literature sources addressing strategising for sustainability identify it as being a continuous process, a continuum towards an ultimate sustainability and business goal (Bonn \& Fisher, 2011:12). The process is viewed as 'gradual, planned, continuous and ongoing incremental change' (Holton et al., 2010:153; Smith \& Sharicz, 2011:5; Velazquez, Esquer, Munguia \& Moure-Eraso, 2011:41). Hallstedt et al. (2010:703) suggest that under the highly pressured and dynamic circumstance in which sustainability has presented itself, companies are adapting to sustainability by emergent means, not having prescriptively planned for it. In fact, a 'future sustainable society' might be so different from the current one that strategists may need to 'first envision the future and invent action pathways' to realise that future. Crews (2010:17) supports this, calling it an 'organic approach.'

The legitimacy theory: is one example of a systems-orientated view of the organisation in relationship with society which allows some focus on the role of communication in disclosure between organisation, government and individuals (Coupland, 2005:356; Cowan et al., 2010:525). From a business's perspective, sustainability has acquired increasing importance because it is considered to be an activity that legitimises an organisation in the eyes of society (Capriotti \& Moreno, 2007:221).

Communicating a focus on sustainability: has become an integral part of the corporate agenda. Companies may use a variety of media, indexes and approaches to discuss sustainability, such as reports, case studies and videos (Reilly, 2009:33). While the number of companies reporting on their sustainability practices has increased in recent years, the genre of the sustainability report and communication has been criticised from both inside and outside corporate walls (Bowers, 2010:250).

The medium of choice for the distribution and leveraging of such reports and communication is the corporate website. The websites are the most public form of communication utilised in efforts to harness the benefits of sustainability (Coupland, 2005:256; Bowers 2010:250). Research indicates a significant rise in the use of corporate websites for reporting TBL activities amongst companies attempting to acknowledge and respond to changing local/national and global societal expectations 
concerning business practices, and to appear favourably in various indexes (Lee et al., 2009). It has been found that sixty-eight percent of the Top 250 Global Fortune 500 companies have embraced sustainability reporting (Gill et al., 2008:244).

A concern regarding the external communication strategies of companies is that it appears that claims are not integrated with strategising and are only surface level (Bowers, 2010:250; Laszlo \& Zhexembayeva, 2011:20). The external communication of a company is an important guide to the public on how companies are integrating sustainability into business practice, especially strategising, but it appears that the sustainability claims cannot always be identified within the context of strategising. There are concerns that claims are simply empty talk and that there is limited adoption of integrated reporting and communication statements made (Adams \& Frost, 2008:288; Uusi-Rauva \& Nurekka, 2010:301). If sustainability reporting and communication are to lead to improvements in sustainability performance, organisations must seek to integrate both physical and financial performance indicators into various aspects of their management functions (Adams \& Frost, 2008:290). It has also been suggested that sustainability embeddedness will derive from displaying greater transparency and honesty, or having conversations as opposed to one-way advertising, or championing collaboration instead of an 'us-versus-them' mentality (Laszlo \& Zhexembayeva, 2011:20; Trendwatching, 2012).

Based on the premise that 'sustainability reporting presents a socially responsible firm, in formal claims and official documents', Riccaboni and Leone (2010:130) propose case-study investigation of sustainability reports in order to investigate if and how external image, reputation and formal claims are 'reflected in internal practices and tools'. Indeed, a company's disclosure should accurately mirror real actions. An honest report will gain greater credibility and preserve legitimacy. A company must ensure its disclosures are a reflection of accurate behaviour (Gill et al., 2008:245; Uusi-Rauva \& Nurekka, 2010:301).

The web is a relatively new context for communication, and commercial websites are treated as public documents, which renders them available to public scrutiny equal to or more stringent than that of the printed form. Corporate websites are geared to 'sell' to audiences, and although theoretically it is possible to create a persona on the web, in practice a company's web presence entails evaluation and accountability. Companies are required to articulate their strategic position with regard to the welfare of all stakeholders (Coupland, 2005:356).

The concept of strategising for sustainability has only recently been reviewed in the literature, having previously been conveyed as a recommendation, for legitimacy purposes, to adhere to compliance obligations, as a warning, or as an argument for companies to adhere to their ethical obligations. This article therefore is interested in determining the level of embeddedness, where sustainability embeddedness is defined as the level at which sustainability elements reveal themselves in the strategising actions of the company. This article is interested in measuring sustainability's position within strategising in order to distinguish companies that are strategising for sustainability from those who just communicate sustainability or respond to specific criteria expected of them to be perceived as sustainable.

The next section explores the research objectives and leads to the research design and the proposed instrument to measure strategising for sustainability.

\section{Research objectives and questions}

What is clear from the literature is that sustainability is a topic of bottom-line importance. Strategising is critical for the harnessing of benefits deriving from sustainability. If companies integrate sustainability with current strategising activities, they can pursue potential competitive advantage. Some leaders aware of legitimacy and concerned for their reputation attempt to placate stakeholders in their efforts to appear sustainable. This is done through reporting on corporate websites which has, however, been criticised as being nothing more than compliance efforts to be politically correct. 
The aim of this research was to ascertain if companies on the JSE ALSI Top 40 were strategising for sustainability, and to create a tool to measure the embeddedness of sustainability. Thus the research questions of this study were: 1 ) Is there evidence that companies are strategising for sustainability in their external communication? (thus companies' sustainable reporting and claims can direct strategising measurement); 2) Can the proposed measurement tool judge 'strategising for sustainability' meaningfully? (thus a measurement tool can be designed to determine the level of sustainability 'embeddedness' in strategising, and measurement can reveal gaps); 3) Are claims about sustainability embedded in strategy or is it just empty talk? (companies' sustainability claims are not embedded into their strategising); 4) Finally, this research was interested in the ability of the SSI tool to discriminate and reveal strategising gaps.

\section{The potential value-add of the study}

The scope and context of reviews of corporate websites for sustainability elements have been limited, and these have not been strategically focused investigations (Capriotti \& Moreno, 2007:221; Bowers, 2010:253; Cowan et al., 2010:524). This research aimed to distinguish companies regarding the degree to which sustainability was strategised for (its embeddedness), thereby taking a more strategic approach to the research, as well as expanding the scope of the research to include all available strategic documents, communication messages and reports on the websites of the Top JSE ALSI Top 40 Companies. Most corporate studies have been done on the Global Fortune Companies or the Indices of Foreign Countries. This research investigated how leading South African companies were reflecting their internal sustainability actions.

The next section describes the research design and the proposed measurement instrument.

\section{RESEARCH DESIGN}

\section{Research approach}

To approach the object of this research and answer the research propositions, a content analysis methodology was applied to the published works and proposed standards, as well as to frameworks on the topics of sustainability and strategy. From the analysis, 10 elements (of strategising) were identified to measure the degree to which sustainability was embedded in the process of strategy formulation and implementation.

With Table 1 as a framework, this research focused on determining the level of embeddedness of sustainability claims in strategising. For this, a framework was proposed and applied to judge the level of the sustainability claims.

Table 1: Research design components

\begin{tabular}{|l|l|}
\hline Component & Description \\
\hline $\begin{array}{l}\text { Research } \\
\text { question / } \\
\text { problem }\end{array}$ & $\begin{array}{l}\text { What is the status of strategising for sustainability? Is there evidence that } \\
\text { sustainability is embedded into strategising? }\end{array}$ \\
\hline Propositions & $\begin{array}{l}\text { P1: Companies' sustainable reporting and claims can direct strategising } \\
\text { measurement. } \\
\text { P2: A measurement tool can be designed to determine the level of sustainability }\end{array}$ \\
& $\begin{array}{l}\text { 'embeddedness' in strategising. } \\
\text { P3: Companies' sustainability claims are not embedded in their strategising } \\
\text { (measured with the tool). } \\
\text { P4: Measurement reveals strategising gaps. }\end{array}$ \\
\hline $\begin{array}{l}\text { Unit of } \\
\text { investigation }\end{array}$ & $\begin{array}{l}\text { Primary - Sustainability reporting and claims } \\
\text { Secondary - Strategising }\end{array}$ \\
\hline Unit of analysis & JSE ALSI Top 40 Companies \\
\hline
\end{tabular}




\begin{tabular}{|l|l|}
\hline $\begin{array}{l}\text { Logic linking the } \\
\text { data to the } \\
\text { propositions }\end{array}$ & $\begin{array}{l}\text { Sustainability is an unavoidable business topic, while the JSE ALSI Top 40 } \\
\text { Companies are the leaders in their industries and in South Africa. Recent literature } \\
\text { has raised concerns regarding strategising for sustainability and the data from this } \\
\text { sample had not been given a strategising for sustainability index. Examining and } \\
\text { measuring the sustainability claims would give direction for sustainability strategising }\end{array}$ \\
\hline $\begin{array}{l}\text { Criteria for } \\
\text { interpreting the } \\
\text { findings }\end{array}$ & $\begin{array}{l}\text { The language used in the communication, together with the reports and claims, would } \\
\text { signal the existence or absence of evidence. } \\
\text { Strategic terms (referring to formulation and implementation) used to describe } \\
\text { strategic initiatives and their levels of sustainability embeddedness were used for } \\
\text { making judgements (See also Annexure A) }\end{array}$ \\
\hline
\end{tabular}

Source: Yin, (2003:21)

\section{Key scientific beliefs of the researchers}

To answer the above questions, the researchers were aware of their own methodological values, beliefs and particular philosophical assumptions. These assumptions could influence the way in which the research was conducted, and are stated here to convey the 'intellectual climate' in which the research was undertaken.

\section{Ontological positions}

This position states the researchers' views and the nature and essence of their research reality. Researcher $A$ is an objective realist who believes that knowledge comes from facts associated with the case and the context. If repetitive and consistent conditions of sustainability claims are found in the top companies, they can be generalised. His interest was to approach the research question from a strategy-as-practice view. Researcher B is a practitioner tasked with development of a company's sustainability strategy. She seeks the truth through objective judgement of best practices and scientific proof.

\section{Epistemological positions}

The theory of knowledge (epistemology) of the researchers diverged to some extent, allowing for interplay on how decisions on social phenomena can be known and how knowledge can be demonstrated.

Researcher A primarily worked from a scientific paradigm supported by a consultant paradigm. Working as a strategy consultant influenced the search for factual directives, business patterns and answers to existing situations of a similar nature. Researcher B worked from an academic learning paradigm in order to meet the requirements for a Master's degree and simultaneously give guidance to the demands she faces as the person contributing to the development of a company's sustainability strategy.

\section{Case study as a research strategy}

A multiple-case approach was used to explain the phenomena within a real-world context where the boundaries between phenomenon and context are not clearly evident. Yin (2003) suggests the uniqueness of a situation as sufficient rationalisation for using a single case. The specific cases under investigation are leading companies in industry. The extent to which companies are strategising for sustainability is believed to be evident through corporate websites and to date this is not readily talked about nor investigated. Most research discusses the reputation aspect of reporting on sustainability, but this proposed tool contributes to distinguishing those companies who are genuine about sustainability. Reasoning was mostly inductive to explore the external communication.

\section{Research method}

Research setting and background: The JSE ALSI Top 40 Companies are deemed to be successful relative to other companies. Due to their ability to read trends and changes in the competitive landscape, these leading companies are aware that consumer and investor markets have changed. The increase in sensitive stakeholders and investors who pay close attention to companies regarding 


\section{Pretorius \\ C. le Roux}

Determining the embeddedness of sustainability claims in strategising: a comparative study of the ALSI 40 companies

their social and environmental actions and the longevity they promote has turned the JSE ALSI Top 40 Companies towards a sustainability focus.

In response to the market changes, the JSE has sought to leverage its unique position within the financial services environment to focus the debate on responsible investment. The JSE launched the Socially Responsible Investment (SRI) index in 2004 in South Africa to provide a measurement of the TBL performance of participating companies. The index offers incentives for compliance and serves as a tool for facilitating responsible investment (Skinner \& Mersham, 2008:239).

To address this new business dimension, preserve reputation and the ability to attract investment, the leading companies have embarked on sustainability reporting and communication. This is attributed to the knowledge that investors use the information on websites (and in reports) to make decisions (Dawkins \& Ngujiri, 2008:236).

Transparent reporting and communication in the public domain are widely considered to be the disclosure of the internal activities and operations of companies. This so-called reflection suggests that what companies say is what companies are doing. This is, however, often far from the truth. Often reporting is a mere compliance activity or just 'empty talk' and therefore appears to lack embeddedness of sustainability in the strategising process. In spite of the bottom-line implications advocating sustainability integration by leading companies, there appears to be a gap between what companies say and what companies do.

Research process: The researchers first embarked on a literature review, followed by the creation of the SSI Tool comprising ten (10) elements based on literature findings. Using the literature and bestpractice findings, the measurement criteria for judging companies were developed. Then the sample was identified and sourced, followed by research on the chosen group. Data was captured, analysed and interpreted.

Development of the Strategising for Sustainability Index (SSI) tool: The SSI tool was formulated through a literature search on strategising for sustainability. The search was of all recent literature by choice of topic. Historical theory-building research was not included in the search because the search was undertaken from the premise that the argument for sustainability in business had already been made. This search focused on the integration of sustainability into corporate strategising. The data was sourced from internet searches of best practice for sustainability, as well as from journals on leading platforms, including: ProQuest, EBSCOHost, Emerald and SABINET. The literature search also included books dealing with the topic. The search terms used included 'sustainability,' 'strategy,' 'strategising,' 'integration of sustainability,' 'triple bottom line,' 'reporting,' 'sustainability measurement' and 'corporate social responsibility.'

The following inclusion criteria for literature sources were applied. The work had to report on:

- The content of sustainability

- The content of strategising

- The tasks and/or activities in strategising for sustainability

- The process, giving suggestions for embedding sustainability

- The challenges associated with strategising and sustainability

- The corporate reporting and communication strategies

- Corporate websites and sustainability

The literature identified then underwent a content analysis by the researchers. The purpose of the research was to identify 10 elements by which the SSI tool could measure the extent to which companies' sustainability was embedded in strategising. The researchers considered three broad concepts: compliance, strategy formulation and strategy implementation. Two elements were identified for compliance; four elements for strategy formulation measurement; and four elements to measure 
strategy implementation. The element titles and criteria were sourced from the content analysis. Support was found for each element.

The measurement scale for judging was developed using the SSI tool as a base. Each of the 10 elements had criteria on a 5-point Likert scale. The scale determined the level of sustainability embeddedness present in each element. The level contributed to describing the overall status of strategising for sustainability. Supporting literature was also used to distinguish the degree of achievement of sustainability embeddedness.

Sampling: The JSE Top 40 listed companies on the All Share Index (ALSI) as of March 2011 were selected as a purposive sample. The JSE SRI Index automatically assesses companies that are in the JSE Top 40. This research selected the same sample size and grouping for assessment, but with the purpose of distinguishing those companies who have truly embedded sustainability from those who make appeasing sustainability claims for reputation purposes. Furthermore, the selected sample generally represented large companies of sound financial standing which had widely traded and marketable shares. These are market leaders and, as such, the assumption is that these companies should direct and set benchmarks for sustainability in their strategising that can be measured.

Data collection methods: The researchers first acquired a list of the Top 40 companies on the All Share Index (ALSI) as of March 2011 quartile reporting. The list was acquired from the JSE. The companies on the list became the target for this research. The researchers designed a measurement tool based on researched elements of strategising as well as from recent literature on the topic on sustainability and its integration in strategising. The proposed SSI tool was then applied to the list. The researchers systematically explored all the content of each company's corporate website. Content included reports, CEO addresses, vision and mission statements and case studies.

Data analyses: Merit for strategising for sustainability was given to a company on the basis that the researcher could interpret the language presented and then use the researcher's discretion as to whether the information would meet the measurement tool's criteria on a 5-point scale. The criteria for each awarded point were based on the definitions of strategic and sustainable terminologies. The researcher developed systems of judgement through application of the SSI tool as the research proceeded.

Data criteria: Each company's data and each element of the scorecard were judged on a Likert-type five-point scale ( 5 being high and 1 being low), with higher scores incorporating higher levels of embeddedness in the strategy. Comprehensive measurement criteria were used to judge the presented data individually and independently for each element of the scorecard instrument. The 10 elements represented compliance (two elements); strategy formulation (four elements); and strategy implementation (four elements).

Strategies employed to ensure quality of data: The researchers were aware of bias, such as the expectation that the highest-ranking companies (based on market capitalisation) would achieve higher levels on the SSI tool index. To deal with this and ensure the data was accurately captured, the researchers made a mental note of this bias and tried to minimise it. To ensure quality of data, data found was immediately captured into a single growing spreadsheet. This served to avoid findings being forgotten and to ensure that data was captured at the time of interpretation by the researcher. Data and findings were preserved through backups at regular intervals to make certain that no data was lost, which could jeopardise the outcome. Furthermore, research was conducted continuously over the course of one month. This contributed to the use of the same mental framework when applying the SSI tool and making judgements.

Reporting the findings: The findings are reported by: firstly presenting the evaluation elements of the proposed SSI tool (based on the literature), secondly stating the key observations and finally responding to the research propositions individually. The style is explanatory, aiming to describe the relationships and finding support (or otherwise) for the propositions set out in Table 1. 


\section{FINDINGS}

\section{Literature findings}

From the literature, 10 elements of sustainability embeddedness were identified and incorporated in the instrument. Each element is described briefly, starting with compliance elements (1-2), thereafter formulation elements (3-6) and finally implementation elements (7-10).

Table 2: Elements of the SSI tool as derived from a content analysis of literature on the topic

\begin{tabular}{|c|c|c|}
\hline $\begin{array}{l}\text { ELEMENT } \\
\text { NUMBER AND } \\
\text { TITLE: }\end{array}$ & DESCRIPTION OF ELEMENT: & $\begin{array}{l}\text { SUPPORTING } \\
\text { AUTHORS: }\end{array}$ \\
\hline \multicolumn{3}{|l|}{ COMPLIANCE: } \\
\hline $\begin{array}{l}1 . \\
\text { INTEGRATED } \\
\text { REPORTING }\end{array}$ & $\begin{array}{l}\text { A product of a process or system of processes } \\
\text { that seeks to inform stakeholders of an organisations } \\
\text { ability to heed to stakeholder and or societal concerns } \\
\text { and to provide meaningful performance information to } \\
\text { support assertions suggesting effective management. } \\
\text { To demonstrate how well an organisation has } \\
\text { embedded a comprehensive view of sustainability into } \\
\text { the strategic fabric of the organisation that leads the } \\
\text { reader to understand whether the organisation is well } \\
\text { placed to adapt to economic, social and environmental } \\
\text { factors. } \\
\text { (the users of an organisation's integrated report } \\
\text { (the stakeholders) should be able to determine from the } \\
\text { report whether the organisation has sufficiently applied } \\
\text { its collective mind in identifying the social, } \\
\text { environmental, economic and financial issues that } \\
\text { impact on the organisation's business, and whether } \\
\text { these issues have been appropriately incorporated into } \\
\text { its strategy. } \\
\text { Reporting ranges from mere compliance, } \\
\text { disclosure and the acknowledgement of sustainability to } \\
\text { an Integrated report. } \\
\text { The accessibility of the report demonstrates a } \\
\text { willingness to disclose information } \\
\quad \text { Excellent reports consider the Global Reporting } \\
\text { Initiative (GRI) Standards, UN Global Compact, JSE } \\
\text { SRI Index, and the ISO } 2600 \text { sustainability reporting } \\
\text { and performance frameworks and communicate a } \\
\text { balance of TBL sustainability indicators }\end{array}$ & $\begin{array}{l}\text { Bowers, 2010:250 } \\
\text { Coupland, 2005:256 } \\
\text { Dawkins \& Ngujiri, } \\
\text { 2008:236. } \\
\text { Gill et al.,, 2008:244 } \\
\text { Ince.motiv, 2010:18 } \\
\text { Rolland \& Bazzoni, } \\
\text { 2009:249 } \\
\text { Smith \& Sharicz, } \\
\text { 2011:78 } \\
\text { Sustainability } \\
\text { Services, (2011). } \\
\text { Uusi-Rauva \& Nurkka, } \\
\text { 2010:300 } \\
\text { Velaquez et } \\
\text { al.,2011:36 }\end{array}$ \\
\hline $\begin{array}{l}2 . \\
\text { SUSTAINABILITY } \\
\text { RECOGNITION } \\
\text { AND } \\
\text { AFFILIATION: }\end{array}$ & $\begin{array}{l}\text { Recognition by third parties can be through } \\
\text { endorsements, awards, partnerships and affiliations. } \\
\text { towards sustainability embeddedness seek connections } \\
\text { with other leading organisations that share the same } \\
\text { beliefs and intentions. } \\
\text { retailer of year' - show a level of accountability for } \\
\text { actions. } \\
\text { Carbon Disclosure Project CDP, displays efforts to go }\end{array}$ & $\begin{array}{l}\text { ACCA } \\
\text { Bonn \& Fisher, } 2011 \\
\text { Cowan et } \\
\text { al.,2010:524; } \\
\text { Searcy, 2009:52 } \\
\text { SRI } \\
\text { Smith \& Sharicz, } \\
\text { 2011:78 }\end{array}$ \\
\hline
\end{tabular}




\begin{tabular}{|c|c|c|}
\hline \multirow{2}{*}{\multicolumn{2}{|c|}{\begin{tabular}{l|l} 
& beyond $r$ \\
STRATECV FORMII
\end{tabular}}} & \\
\hline & \multicolumn{2}{|c|}{ STRATEGY FORMULATION } \\
\hline $\begin{array}{l}3 . \\
\text { VISION \& } \\
\text { MISSION } \\
\text { INCLUDES } \\
\text { SUSTAINABILITY }\end{array}$ & $\begin{array}{l}\text { Vision and mission statements and the core } \\
\text { values of a business are crucial to the formulation of } \\
\text { strategy. } \\
\text { core values demonstrate the focus and intent of the } \\
\text { organisation towards sustainability. } \\
\text { A sustainability philosophy, statement from the } \\
\text { CEO or a sustainability slogan does not demonstrate a } \\
\text { high level of embeddedness and in fact can portray half } \\
\text { heartedness by the company. } \\
\text { All three elements of sustainability and the } \\
\text { word itself should be on the front page of the website } \\
\text { and both in the annual report and the sustainability } \\
\text { section. }\end{array}$ & $\begin{array}{l}\text { Adams \& Frost, } \\
\text { 2008:288 } \\
\text { Bonn \& Fisher, 2011:6 } \\
\text { Bowers, 2010:249 } \\
\text { Carpenter \& Sanders } \\
\text { 2009:35 } \\
\text { Coupland, 2005:356 } \\
\text { Capriotti \& Moreno, } \\
\text { 2007:221 } \\
\text { Leon-Soriana et al., } \\
\text { 2010:252 } \\
\text { Lynch, 2009:490 } \\
\text { Reilly, 2009:34 } \\
\text { Searcy, 2009:52 }\end{array}$ \\
\hline $\begin{array}{l}4 . \\
\text { RISK } \\
\text { MANAGEMENT: } \\
\text { MACROECONOMI } \\
\text { C } \\
\text { IDENTIFICATION } \\
\text { OF RISKS AND } \\
\text { OPPORTUNITIES }\end{array}$ & $\begin{array}{l}\text { A connection between sustainability risks and } \\
\text { company strategy formulation affecting strategic, } \\
\text { operational and tactical decisions. } \\
\text { The company should identify the } \\
\text { macroeconomic and industry risks and opportunities } \\
\text { associated with sustainability. } \\
\text { companies need to acknowledge the impact of } \\
\text { climate change and social challenges and the role the } \\
\text { company plays in achieving sustainability. } \\
\text { There should be a visible system to manage } \\
\text { the risk including a model or clear plans. }\end{array}$ & $\begin{array}{l}\text { Lynch, 2009:351 } \\
\text { KING III } \\
\text { Riccaboni \& Leone, } \\
\text { 2010:130 } \\
\text { Searcy, 2009:50 } \\
\text { Velaquez et al., } \\
2011: 36\end{array}$ \\
\hline \multicolumn{3}{|c|}{ STRATEGY IMPLEMENTATION: } \\
\hline $\begin{array}{l}5 . \\
\text { PROGRAMMES \& } \\
\text { STAFF } \\
\text { LEARNING }\end{array}$ & $\begin{array}{l}\text { To harness the staff buy-in, companies need to } \\
\text { train and educate employees on sustainability } \\
\text { embedded company goals and educate them on their } \\
\text { role in the desired outcome. } \\
\text { - Staff are seen as critical to the success of a } \\
\text { strategy and, as such, pivotal to one that incorporates } \\
\text { sustainability. } \\
\text { c Employee engagement has an impact on } \\
\text { company performance and embedding social and } \\
\text { environmental considerations into the company's } \\
\text { operations spurs engagement and the achievement of } \\
\text { financial return and an embedded sustainability } \\
\text { strategy. } \\
\text { L Learning and education are fundamental } \\
\text { methods to communicate to staff the 'revolutionary' } \\
\text { drive towards a shift to sustainability } \\
\text { - Photos from sustainability awareness contract } \\
\text { sessions, campaigns, drives, community outreach and } \\
\text { formal training with staff demonstrate embeddedness of } \\
\text { sustainability in strategising. }\end{array}$ & $\begin{array}{l}\text { Elmualim et al., } \\
\text { 2010:58 } \\
\text { Holton et al. 2010:157 } \\
\text { Klaine \& Von Hauff, } \\
\text { 2009:520 } \\
\text { Lynch, 2009:550 } \\
\text { Laszlo \& } \\
\text { Zhexembayeva, } \\
\text { 2011:20; } \\
\text { Reilly, 2009:34 } \\
\text { Lacy et al., 2009:491 } \\
\text { Reilly, 2009:34 } \\
\text { White, 2009:392 }\end{array}$ \\
\hline $\begin{array}{l}6 . \\
\text { SPECIFIC GOALS } \\
\text { AND } \\
\text { OBJECTIVES TO } \\
\text { ACHIEVE } \\
\text { SUSTAINABILITY: }\end{array}$ & $\begin{array}{l}\text { A firm's goals and objectives are commitments } \\
\text { to actions to achieve the strategic vision of the } \\
\text { company } \\
\text { sustainability focus } \\
\text { - Sustainability embeddedness is determined }\end{array}$ & $\begin{array}{l}\text { Lynch, 2009:491 } \\
\text { Lee et al., 2009:146 } \\
\text { Riccaboni \& Leone, } \\
\text { 2009:36 }\end{array}$ \\
\hline
\end{tabular}




\begin{tabular}{|c|c|c|}
\hline & $\begin{array}{l}\text { through communicating specific sustainability } \\
\text { statements that are visible to stakeholders } \\
\text { integrating sustainability into our strategy.' }\end{array}$ & \\
\hline $\begin{array}{l}7 . \\
\text { CLEAR } \\
\text { SUSTAINABILITY } \\
\text { INITIATIVES AND } \\
\text { PROGRAMMES }\end{array}$ & $\begin{array}{l}\text { Actions and initiatives are tangible efforts that } \\
\text { serve as evidence that a company has interacted with } \\
\text { stakeholders and made a commitment of resources } \\
\text { - The actions need to be aligned with corporate } \\
\text { goals and vision and should not just be ad hoc projects } \\
\text { - Sustainability actions and projects display } \\
\text { decision making in the direction of sustainability through } \\
\text { the commitment of resources and capital outlay. }\end{array}$ & $\begin{array}{l}\text { Bonn \& Fisher, } \\
\text { 2011:7; Hallstedt et } \\
\text { al.,2010:703 } \\
\text { Holton et al.,2010:152 } \\
\text { Riccaboni \& Leone, } \\
\text { 2010:36 } \\
\text { Reilly, 2009:35 }\end{array}$ \\
\hline $\begin{array}{l}8 . \\
\text { DEDICATED } \\
\text { STAFF FOR } \\
\text { SUSTAINABILITY }\end{array}$ & $\begin{array}{l}\text { Good governance is essentially about effective } \\
\text { leadership. Leaders need to define strategy, provide } \\
\text { direction and establish the ethics and values that will } \\
\text { influence and guide practices and behaviour with } \\
\text { regard to sustainability performance. } \\
\text { - For the achievement of a sustainable } \\
\text { organisation, responsible leadership, are required to be } \\
\text { change agents. } \\
\text { leadership level portrays accountability and } \\
\text { governance. } \\
\text { suggest sustainability is truly being implemented. } \\
\quad \text { Involving staff at middle and operational levels } \\
\text { individuals and teams for sustainability } \\
\text { - Implementation of a sustainability embedded } \\
\text { strategy is evident from names/photos and titles of } \\
\text { sustainability dedicated staff. }\end{array}$ & $\begin{array}{l}\text { Adams \& Frost, } 2008 \\
\text { Bonn \& Fisher, } \\
2011: 12 \\
\text { Cowan et } \\
\text { al.,2010:154 } \\
\text { Holton et al. } \\
\text {,2010:152 } \\
\text { Klaine \& Von Hauff, } \\
\text { 2009:520 } \\
\text { Lynch, 2009:492 } \\
\text { Quinn \& Dalton, } \\
\text { 2009:21 } \\
\text { Reilly, 2009:34 } \\
\text { Uusi-Rauva, } 2010: 300 \\
\text { White, 2009:329 }\end{array}$ \\
\hline $\begin{array}{l}9 . \\
\text { SPECIFIC } \\
\text { MEASURES AND } \\
\text { TARGETS: }\end{array}$ & $\begin{array}{l}\text { Companies that communicate specific } \\
\text { measures and targets for sustainability portray } \\
\text { embeddedness of sustainability in the implementation } \\
\text { of strategy. } \\
\text { - The disclosure of successes or failures towards } \\
\text { set goals and objective on a year on year basis shows } \\
\text { progressive improvement. } \\
\text { to sustainability. } \\
\text { - Performance management systems, e.g. } \\
\text { Balanced Scorecards and Key Performance Indicators } \\
\text { for sustainability targets indicate commitment. } \\
\text { - Companies that use both qualitative and } \\
\text { quantitative means to describe the achievement on } \\
\text { efforts towards sustainability reveal embeddedness. }\end{array}$ & $\begin{array}{l}\text { Bonn \& Fisher, 2016 } \\
\text { Holton et al.,2010:152 } \\
\text { Lacy et al.,2009:491 } \\
\text { Leon-Soriano et al., } \\
\text { 2010:249 } \\
\text { Quinn \& Dalton, } \\
\text { 2007:21 } \\
\text { Riccaboni \& Leone, } \\
\text { 2010:130 } \\
\text { Smith \& Sharicz, } \\
\text { 2011:73: } \\
\text { Searcy, 2009:50 }\end{array}$ \\
\hline $\begin{array}{l}10 . \\
\text { SUSTAINABILITY } \\
\text { INNOVATION: }\end{array}$ & $\begin{array}{l}\text { Sustainability innovation encapsulates the } \\
\text { ability of the company to allow for sustainability to } \\
\text { inform strategy decisions. } \\
\text { aspects of any transition to sustainability } \\
\text { embeddedness - innovation provides new ways of } \\
\text { doing things, including profitable responses to } \\
\text { sustainability. } \\
\text { - The cost of implementing sustainability is a }\end{array}$ & $\begin{array}{l}\text { Bonn \& Fisher, } \\
2011: 11 \\
\text { Collins et al., } \\
2007: 736 . \\
\text { Holton et al., } \\
2010: 157 \\
\text { Laszlo \& } \\
\text { Zhexembayeva, } \\
2011: 20\end{array}$ \\
\hline
\end{tabular}


M. Pretorius

C. le Roux

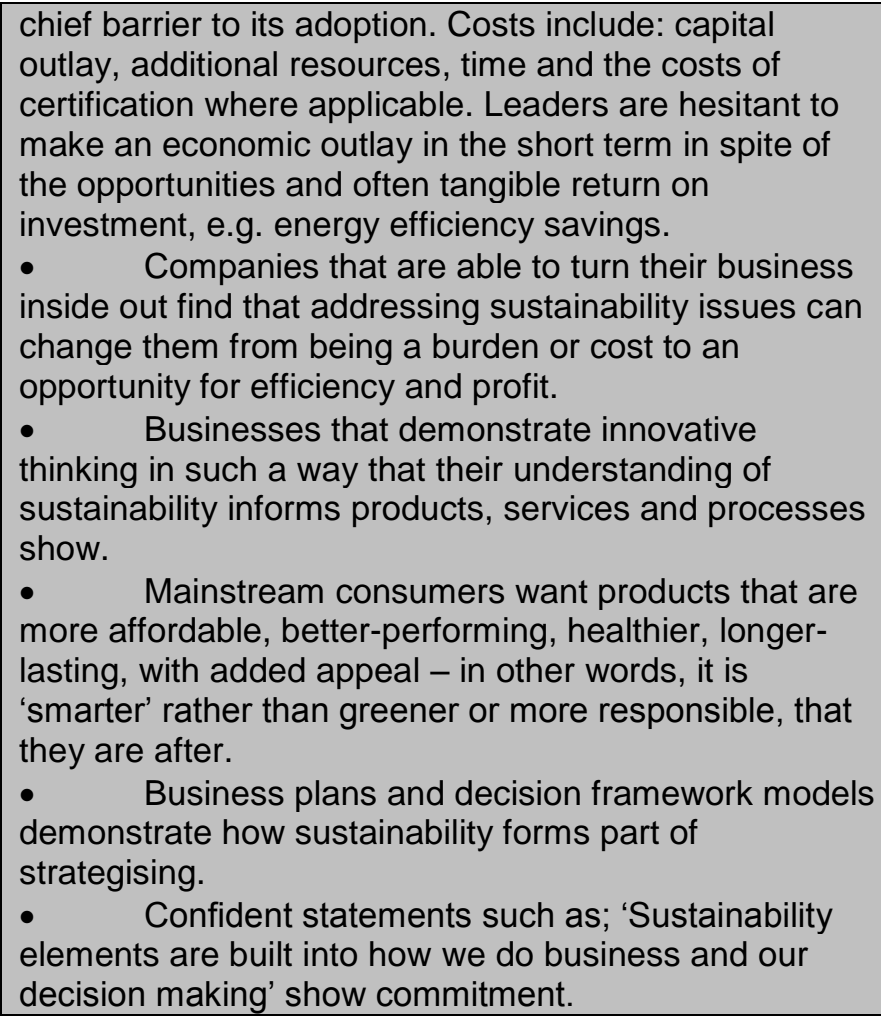

\section{Empirical findings}

Tables 3 to 4 and Figure 1 present the empirical findings after application of the SSI tool to the ALSI Top 40 Companies. The findings are presented as support (or otherwise) for the propositions and thereby give perspective by seeking insights.

\section{P1: Companies' sustainable reporting and claims can direct strategising measurement \\ Supported}

Firstly, it was possible for the researcher to use the SSI tool and measurement criteria and apply them to the sustainability reporting and claims for each company. Secondly, each element could be judged on the unique scale for the specific element. Aggregating the scores led to an overall score that could be used to rank the sample companies for SSI. Table 3 shows the outcome of the evaluation process. In spite of well-structured sentences, strategic word choice and creative communication strategies, the actual level of sustainability embeddedness could be measured. The researcher could make meaningful judgements using the evaluation scales for each element. 
M. Pretorius

C. le Roux
Determining the embeddedness of sustainability claims in strategising: a comparative study of the ALSI 40 companies

Table 3: Evaluation results of the Top 40 Companies based on the Strategising for

Sustainability index (SSI) measurement tool, with individual elements and rankings

\begin{tabular}{|c|c|c|c|c|c|c|c|c|c|c|c|c|c|}
\hline & & \multicolumn{9}{|c|}{ ELEMENTS } & \multirow{2}{*}{$\begin{array}{l}\text { MARKET } \\
\text { CAP } \\
\text { RANK }\end{array}$} & \multirow{2}{*}{$\begin{array}{l}\text { SSI } \\
\text { SCORE }\end{array}$} & \multirow{2}{*}{$\begin{array}{l}\text { SSI * } \\
\text { RANK }\end{array}$} \\
\hline & 1 & 2 & 3 & 4 & 5 & 6 & 7 & 8 & 9 & 10 & & & \\
\hline BHP & 5 & 4 & 4 & 4 & 3 & 4 & 4 & 3 & 5 & 5 & 1 & 41 & 12 \\
\hline $\begin{array}{l}\text { ANGLO } \\
\text { AMERICAN }\end{array}$ & 5 & 3 & 5 & 5 & 4 & 5 & 5 & 3 & 5 & 5 & 2 & 45 & 4 \\
\hline SAB MILLER & 5 & 5 & 5 & 5 & 4 & 5 & 5 & 3 & 5 & 5 & 3 & 47 & 1 \\
\hline SASOL & 4 & 4 & 5 & 5 & 5 & 5 & 4 & 3 & 4 & 5 & 4 & 44 & 6 \\
\hline MTN & 4 & 5 & 3 & 5 & 4 & 3 & 4 & 4 & 3 & 5 & 5 & 40 & 14 \\
\hline $\begin{array}{l}\text { COMPAGNIE } \\
\text { FIN }\end{array}$ & 3 & 2 & 1 & 2 & 2 & 3 & 3 & 2 & 3 & 1 & 6 & 22 & 39 \\
\hline $\begin{array}{l}\text { ANGLO } \\
\text { PLATINUM }\end{array}$ & 4 & 5 & 3 & 5 & 4 & 4 & 5 & 5 & 4 & 5 & 7 & 44 & 6 \\
\hline NASPERS & 3 & 2 & 2 & 2 & 2 & 1 & 2 & 2 & 2 & 2 & 8 & 20 & 40 \\
\hline $\begin{array}{l}\text { STANDARD } \\
\text { BANK }\end{array}$ & 3 & 5 & 3 & 4 & 2 & 2 & 2 & 4 & 3 & 3 & 9 & 31 & 34 \\
\hline $\begin{array}{l}\text { KUMBA IRON } \\
\text { ORE }\end{array}$ & 3 & 5 & 2 & 4 & 3 & 3 & 4 & 3 & 4 & 3 & 10 & 35 & 26 \\
\hline IMPALA PLAT & 5 & 3 & 5 & 3 & 3 & 5 & 3 & 5 & 4 & 3 & 11 & 39 & 16 \\
\hline ANGLOGOLD & 4 & 2 & 3 & 4 & 2 & 3 & 4 & 3 & 5 & 3 & 12 & 33 & 30 \\
\hline VODACOM & 4 & 3 & 2 & 4 & 4 & 3 & 4 & 3 & 3 & 3 & 13 & 33 & 30 \\
\hline FIRSTRAND & 4 & 4 & 3 & 4 & 5 & 3 & 4 & 3 & 4 & 4 & 14 & 38 & 19 \\
\hline ABSA & 4 & 4 & 3 & 4 & 4 & 3 & 3 & 3 & 4 & 4 & 15 & 36 & 25 \\
\hline GOLD FIELDS & 5 & 5 & 5 & 5 & 4 & 5 & 4 & 4 & 5 & 5 & 16 & 47 & 1 \\
\hline OLD MUTUAL & 5 & 5 & 3 & 4 & 5 & 3 & 4 & 4 & 4 & 3 & 17 & 40 & 14 \\
\hline NEDBANK & 5 & 5 & 5 & 4 & 4 & 5 & 5 & 3 & 5 & 4 & 18 & 45 & 4 \\
\hline SANLAM & 4 & 4 & 3 & 3 & 4 & 4 & 4 & 5 & 3 & 4 & 19 & 38 & 19 \\
\hline BIDVEST & 4 & 4 & 4 & 3 & 3 & 3 & 3 & 4 & 4 & 3 & 20 & 35 & 26 \\
\hline EXXARO & 5 & 4 & 5 & 4 & 3 & 5 & 5 & 3 & 3 & 4 & 21 & 41 & 12 \\
\hline REMGRO & 5 & 3 & 2 & 2 & 4 & 3 & 3 & 3 & 3 & 3 & 22 & 31 & 34 \\
\hline SHOPRITE & 3 & 2 & 2 & 3 & 2 & 3 & 3 & 2 & 3 & 2 & 23 & 25 & 37 \\
\hline RMB & 4 & 4 & 5 & 4 & 5 & 4 & 5 & 4 & 3 & 4 & 24 & 42 & 10 \\
\hline A.R.M & 5 & 3 & 3 & 4 & 3 & 4 & 4 & 5 & 4 & 4 & 25 & 39 & 16 \\
\hline INVESTEC & 5 & 4 & 5 & 3 & 5 & 4 & 3 & 5 & 4 & 5 & 26 & 43 & 8 \\
\hline LONMIN & 5 & 3 & 5 & 3 & 4 & 3 & 3 & 3 & 5 & 4 & 27 & 38 & 19 \\
\hline ARCELOR MIT & 5 & 4 & 5 & 4 & 5 & 4 & 5 & 5 & 4 & 5 & 28 & 46 & 3 \\
\hline STEINHOFF & 3 & 1 & 3 & 3 & 3 & 4 & 5 & 3 & 3 & 4 & 29 & 32 & 32 \\
\hline CAPSHOP & 3 & 5 & 3 & 2 & 3 & 3 & 5 & 2 & 3 & 3 & 30 & 32 & 32 \\
\hline ASPEN & 3 & 4 & 2 & 3 & 2 & 3 & 3 & 3 & 3 & 3 & 31 & 29 & 35 \\
\hline HARMON & 5 & 4 & 3 & 4 & 2 & 4 & 5 & 3 & 5 & 4 & 32 & 39 & 16 \\
\hline TIGERBRAND & 5 & 4 & 3 & 4 & 3 & 3 & 4 & 3 & 4 & 4 & 33 & 37 & 22 \\
\hline MONDI & 5 & 5 & 4 & 4 & 4 & 4 & 5 & 3 & 4 & 5 & 34 & 43 & 8 \\
\hline MASSMART & 5 & 4 & 5 & 4 & 3 & 4 & 5 & 3 & 4 & 5 & 35 & 42 & 10 \\
\hline TRUWORTHS & 5 & 4 & 4 & 4 & 2 & 3 & 4 & 2 & 5 & 4 & 36 & 37 & 22 \\
\hline
\end{tabular}


M. Pretorius

C. le Roux
Determining the embeddedness of sustainability claims in strategising: a comparative study of the ALSI 40 companies

\begin{tabular}{|l|l|l|l|l|l|l|l|l|l|l|l|l|l|}
\hline $\begin{array}{l}\text { AFRICAN } \\
\text { BANK }\end{array}$ & $\mathbf{3}$ & $\mathbf{3}$ & $\mathbf{3}$ & $\mathbf{2}$ & $\mathbf{5}$ & $\mathbf{4}$ & $\mathbf{4}$ & $\mathbf{3}$ & $\mathbf{4}$ & $\mathbf{3}$ & 37 & 34 & 29 \\
\hline ASSORE & $\mathbf{3}$ & $\mathbf{2}$ & $\mathbf{2}$ & $\mathbf{3}$ & $\mathbf{3}$ & $\mathbf{2}$ & $\mathbf{3}$ & $\mathbf{3}$ & $\mathbf{3}$ & $\mathbf{2}$ & 38 & 26 & 36 \\
\hline GROWTHPOINT & $\mathbf{3}$ & $\mathbf{4}$ & $\mathbf{3}$ & $\mathbf{3}$ & $\mathbf{3}$ & $\mathbf{4}$ & $\mathbf{4}$ & $\mathbf{4}$ & $\mathbf{3}$ & $\mathbf{3}$ & 39 & 34 & 28 \\
\hline IMPERIAL & $\mathbf{4}$ & $\mathbf{3}$ & $\mathbf{3}$ & $\mathbf{4}$ & $\mathbf{3}$ & $\mathbf{4}$ & $\mathbf{5}$ & $\mathbf{3}$ & $\mathbf{4}$ & $\mathbf{4}$ & 40 & 37 & 22 \\
\hline Element Means & $\mathbf{4 . 1 8}$ & $\mathbf{3 . 7 3}$ & $\mathbf{3 . 4 8}$ & $\mathbf{3 . 6 5}$ & $\mathbf{3 . 4 5}$ & $\mathbf{3 . 6 0}$ & $\mathbf{3 . 9 8}$ & $\mathbf{3 . 3 5}$ & $\mathbf{3 . 8 3}$ & $\mathbf{3 . 7 5}$ & & $\mathbf{3 7 . 0 0}$ & \\
\hline
\end{tabular}

* Where companies had the same SSI score, they were allocated the same ranking but placed in the table based on their market capitalisation

${ }^{*}$ Rank is determined on the scores in that 1 is the highest and 40 is the lowest

P2: A measurement tool can be designed to determine the level of sustainability 'embeddedness' in strategising

Supported

The SSI measurement tool can be used to describe the level of strategising embeddedness. Table 3 demonstrates the results of measuring the level of sustainability embeddedness in strategising. The SSI tool's framework is based on input of literature and on the foundation of strategic principles. The 5 -point scale on the SSI tool serves to describe the achievement of the company for each element.

This proposed SSI tool addresses the potentially 'superfluous' claims surrounding sustainability and puts into perspective those companies who have successfully demonstrated that sustainability is not just for reputation purposes and is in fact part of their strategising and operating as a listed company. Figure 1 shows a graphical depiction of some sample companies to indicate the value of comparing an individual company's SSI performance against others, thereby identifying gaps to which to direct management's attention.

Figure 1: Comparative depiction of the SSI element scores for three sample companies compared with the overall mean scores per element

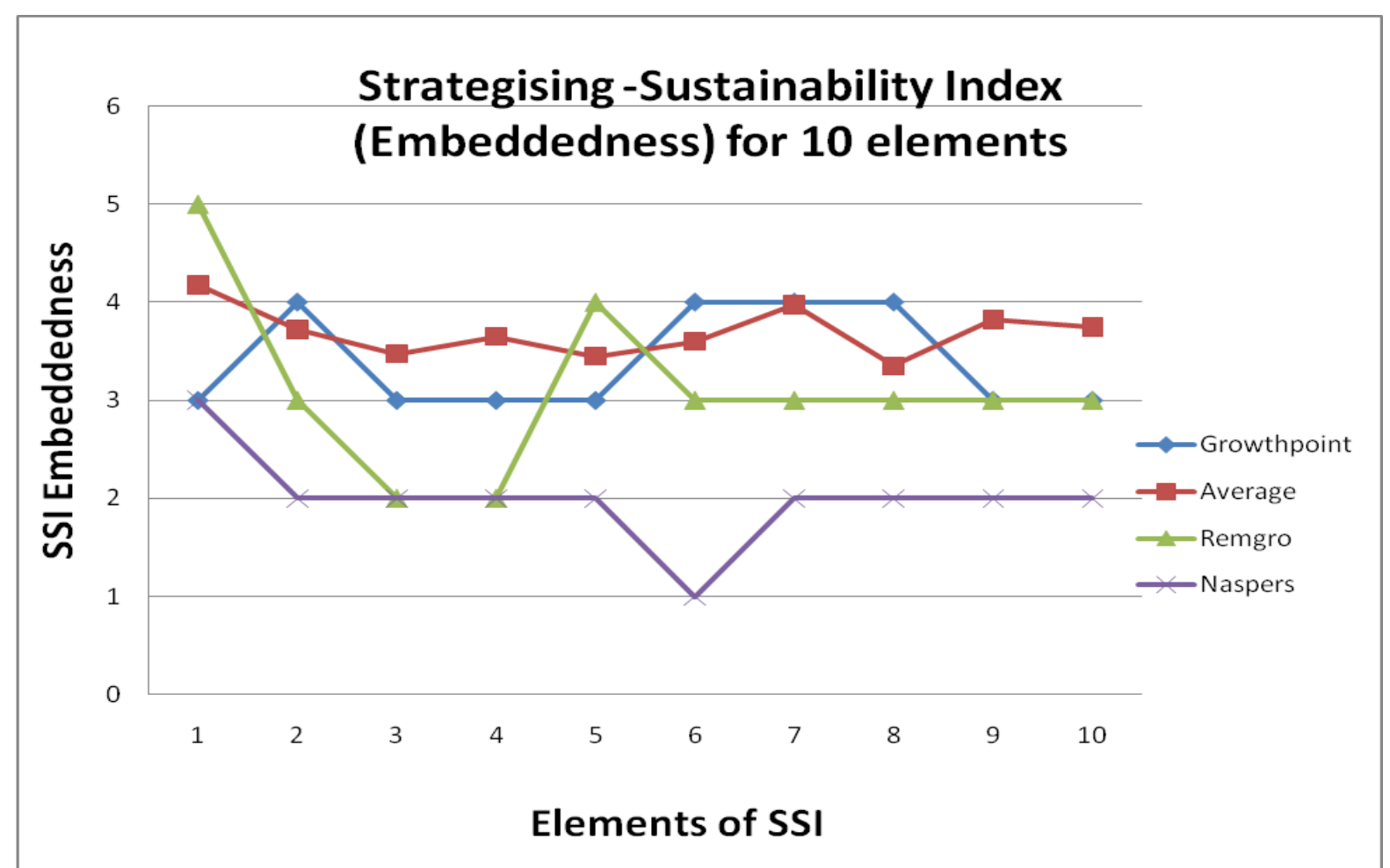

Table 4: Comparison of SSI elements based on different criteria whereby groups were analysed on SSI index and Market Capitalisation. 


\begin{tabular}{|l|l|l|l|l|l|l|l|l|l|l|l|}
\hline ELEMENT & $\mathbf{1}$ & $\mathbf{2}$ & $\mathbf{3}$ & $\mathbf{4}$ & $\mathbf{5}$ & $\mathbf{6}$ & $\mathbf{7}$ & $\mathbf{8}$ & $\mathbf{9}$ & $\mathbf{1 0}$ & TOTAL \\
\hline $\begin{array}{l}\text { SSI AVERAGE } \\
\text { /ELEMENT }\end{array}$ & 4.18 & 3.73 & 3.48 & 3.65 & 3.45 & 3.60 & 3.98 & 3.35 & 3.83 & 3.75 & 37.00 \\
\hline $\begin{array}{l}\text { MEAN TOP 10 } \\
\text { BASED ON SSI }\end{array}$ & 4.70 & 4.40 & 4.70 & 4.40 & 4.40 & 4.50 & 4.60 & 3.80 & 4.30 & 4.80 & 44.60 \\
\hline $\begin{array}{l}\text { MEAN BOTTOM 10 } \\
\text { BASED ON SSI }\end{array}$ & 3.30 & 2.90 & 2.20 & 2.80 & 2.70 & 2.70 & 3.30 & 2.70 & 2.90 & 2.60 & 28.10 \\
\hline $\begin{array}{l}\text { MEAN TOP 10 } \\
\text { BASED ON M CAP }\end{array}$ & 3.90 & 4.00 & 3.30 & 4.10 & 3.30 & 3.50 & 3.80 & 3.20 & 3.80 & 3.90 & 36.90 \\
\hline $\begin{array}{l}\text { MEAN BOTTOM 10 } \\
\text { BASED ON M CAP }\end{array}$ & 4.10 & 3.70 & 3.20 & 3.50 & 3.00 & 3.50 & 4.20 & 3.00 & 3.90 & 3.70 & 35.80 \\
\hline
\end{tabular}

\section{P3: Companies' sustainability claims are not embedded in their strategising}

Not supported - sustainability claims are partially embedded and not equally embedded. The overall average for the level of sustainability claims embedded in strategising is seventy-four percent. Sustainability claims are, however, not equally embedded in the Top 40 companies' strategising process. This is apparent when interpreting the data from research on the elements pertaining to the formulation and implementation as strategising elements. See Tables 4 and 5 for comparison.

The mean scores for the Top 10 companies based on Market Capitalisation are 2.55 for formulation and 3.55 for implementation. Similarly, the mean score for the Top 10 companies on the SSI index are 3.25 for formulation and 4.33 for implementation respectively. The sustainability claims of these companies are not equally embedded in the process of strategising. While companies did score embeddedness ratings out of 5 , it was found that the score was lower for the formulation elements, raising the question of whether projects (forming part of implementation efforts) are not implemented on an ad-hoc basis when they are not necessarily formulated as part of a strategy.

Sustainability claims were found to be partially embedded in strategising, depending on whether formulation or implementation components were judged. When judging the formulation elements, it was determined that there was a level of sustainability embeddedness. The results of all companies on the four formulation elements averaged at 2.62, indicating a level of embeddedness of sustainability claims. Incorporating sustainability in the formulation process does not, however, necessarily 'prove' real incorporation of sustainability. Companies on the Top 40 JSE cannot communicate sustainability embeddedness through claims in the formulation elements only. Embedded sustainability requires proof from the implemented strategy - thus, concrete outputs are required. Companies appear to focus on the implementation aspects of strategising and this is a contributing reason why the average embeddedness rating for implementation was a high score of 3.70 .

The last four elements of the SSI tool measured the sustainability claims of companies in strategy implementation, and in spite of the 3.70 embeddedness rating, the researchers determined that sustainability claims were not always embedded in strategy implementation. This is why embeddedness in strategising is said to be partially embedded. In circumstances where companies in the study were able to demonstrate programmes and initiatives in all the implementation elements and show case studies of the efforts or projects, they were awarded the highest level of embeddedness. Seventy-four percent of companies could demonstrate they had embedded aspects of sustainability in the elements of implementation. 

M. Pretorius
C. le Roux

There was, however, a tendency to discuss ad-hoc social initiatives, which do form part of TBL sustainability but do not form part of balanced sustainability implementation communication. On other occasions, companies communicated a balance of sustainability programmes in spite of not having a sustainability vision and mission or objectives. Companies found creative ways to demonstrate sustainability embeddedness in implementation, which appealed to the SSI elements and to individual criteria in the measurement instrument. Regarding the element of specific measures and targets, companies displayed clear year-on-year improvement (on sustainability initiatives), yet sometimes failed to provide a baseline or only displayed the results using percentages.

While the score for sustainability embeddedness is on the whole quite satisfactory, the researchers need to emphasise that there are concerns about the strategising practices of companies specifically with reference to the dedicated leadership element. The average level of sustainability embeddedness for dedicated staff - those intended to carry out the implementation of sustainability - had the lowest average, of 3.35 out of 5 . When matching this to the SSI tool's measurement criteria, it can be interpreted as follows: the company has mentioned a sustainability (or risk) committee as its dedicated staff; however, there are no operational or tactical staff mentioned. The lack of tactical and operational staff among the companies surely affects their ability to strategise for sustainability, which implies that sustainability claims are partially embedded in strategising.

\section{P4: Measurement reveals strategising gaps}

\section{Supported}

The findings support that there were strategising gaps. Figure 1 graphically depicted the strategising gaps through a comparative assessment. Table 5 compares and displays the discrepancy between the scores for formulation and implementation of sustainability embeddedness. Most companies nevertheless scored high on compliance, suggesting that the approach to strategising for sustainability may be compliance driven.

Table 5: Comparison of SSI elements based on different strategising components of formulation and compiled on SSI index and Market Capitalisation

\begin{tabular}{|l|l|l|l|l|l|l|l|}
\hline & & & & & \multicolumn{2}{|l|}{} & \\
\hline STRATEGISING ELEMENT & \multicolumn{2}{|l|}{ COMPLIANCE } & \multicolumn{2}{|l|}{ FORMULATION } & \multicolumn{2}{|l|}{ IMPLEMENTATION } \\
\hline SSI MEAN /ELEMENT & 3.95 & & 2.62 & 3.70 & & \\
\hline MEAN TOP 10 BASED ON SSI & 4.55 & & 3.25 & & 4.33 & & \\
\hline $\begin{array}{l}\text { MEAN BOTTOM 10 BASED ON } \\
\text { SSI }\end{array}$ & 3.10 & & 2.05 & 2.99 & & \\
\hline $\begin{array}{l}\text { MEAN TOP 10 BASED ON M } \\
\text { CAP }\end{array}$ & 3.95 & & 2.55 & & 3.55 & & \\
\hline $\begin{array}{l}\text { MEAN BOTTOM 10 BASED ON } \\
\text { M CAP }\end{array}$ & 3.90 & & 2.56 & & 3.72 & & \\
\hline
\end{tabular}

In the process of strategising, formulation and implementation generally occur in sequence (implementation after formulation), or in the case of an emergent strategy, they may occur simultaneously. In unusual cases, implementation can be recorded without formulation, and this would be counter-intuitive to the process of strategising. The SSI tool measured sustainability within the elements of strategising and the level to which the sustainability claim was embedded. The process has revealed strategising gaps in companies.

The higher score for implementation than formulation exposes companies who had prepared good communication strategies or conveyed some 'green washing' in the company. In other words, while 
the company report was mere compliance (and thus the high score for compliance), they displayed cases of ad-hoc implementation efforts to show the stakeholders they were involved in sustainability efforts. These implementation sustainability claims were measured in the strategising elements and revealed the overall strategising gaps when compared with formulation scoring.

Some companies met the measurement criteria and requirements for elements of sustainability implementation in spite of the fact that their initiatives often lacked incorporation in the vision or specific sustainability objective. This attests to the ability of the SSI tool to expose strategising gaps. Company representatives are 'savvy', and understand that investors are interested in the fundamental strategy elements in order to ascertain the existence of sustainability. Guidelines such as GRI also propose that companies refer to certain key indicators. The existence of sustainability claims in elements does not necessarily mean that the company is strategising for sustainability.

The SSI tool therefore has discrimination value and is able to measure sustainability in the context of strategising and reveal strategising gaps resulting from strategic marketing and communication efforts by companies. This is demonstrated by understanding the process of strategising and interpreting the findings.

\section{DISCUSSION}

The research has determined the level of embeddedness of sustainability claims in the strategising of the JSE Top 40. The findings and answers to the propositions contribute to describing the status of strategising for sustainability in these leading companies. The research explored the extent of sustainability embeddedness in strategising in their external communication. Following are some discussion points from the research:

The average score for the integrated report (element 1) was 4.18. This high score out of 5 can be attributed to the presentation of fully integrated reports that disclose information on each element of sustainability in a balanced way, according to established reporting guidelines of KING III. Companies that scored a full five points were able to assure the researcher that they had gone to great lengths to produce an integrated report and make it accessible on the website. These companies also asserted that they complied with KING III and the GRI guidelines. Examples of companies who were able to demonstrate this basic compliance element with the greatest success were BHP, Impala Platinum and Goldfields. The companies referred to their disclosure of sustainability under the heading of 'sustainability' and not CSR. They also presented the sustainability sections of the report in the same way as the financial results - with the intention that they be read and analysed by investors.

The connection between strategising for sustainability and compliance has to do with the company outlook. Good compliance demonstrates that the company, either proactively or reactively, is responding to the concept of sustainability by formulating a strategy and plan. Good compliance is further demonstrated when companies adhere to volunteer reporting standards such as the Carbon Disclosure Project (CDP). The CDP also requires that companies report on strategising for sustainability in the company. The mean compliance score was 3.95. This indicated a fairly high level of compliance by companies on the JSE ALSI 40.

The average score for a vision and mission including sustainability (element 3 ) was 3.48 and the clear sustainability initiatives and programmes (element 7) achieved an average of 3.98. These scores suggest that there was more embeddedness of sustainability in programmes implemented (associated with element 7 ) in spite of a lower score for embeddedness in planning and formulation (element 3 ). This was confirmed by the overall mean for the formulation elements (2.62), in contrast to the mean for implementation elements (3.70).

Support for the counter-intuitive finding of greater implementation than formulation is best described when looking at the dedicated leadership for sustainability (element number 8 , forming part of implementation). It was the only element that was scored below 4 points among the Top $10 \mathrm{SSI}$ 
companies. The mean score was 3.35 , which was lower than the implementation mean score for sustainability programmes and initiatives: 3.98. This raises questions around the strategising for sustainability of companies; how are companies that communicate sustainability initiatives implementing these initiatives when they do not have sustainability staff positioned to carry them out? This finding suggests that companies have strategising gaps, which highlights an area for future research.

The SSI tool is considered an effective tool for determining sustainability embeddedness owing to its ability to offer discriminating value and reveal strategising gaps. This is supported by the following findings and statements:

- The Top 10 companies based on market capitalisation scored only 2.55 for formulation and 3.55 for implementation. In contrast, the Top 10 companies who (overall) scored the highest in the SSI index reveal a 3.25 score for the formulation elements and a 4.33 for the implementation elements. These high-scoring SSI companies were not the highest market-capital companies, yet had much higher embeddedness ratings. This may suggest that the SSI tool does discriminate between companies on sustainability embeddedness.

- The JSE SRI index's five best-performing companies all fall within the range of 1 and 16 when positions are ranked by market capitalisation. The SSI tool's Top 5 scoring companies fall within the range of 1 to 28 in the rank by market capitalisation (refer to Table 3). Only two companies scored in the Top 5 for both the SRI Index and on the SSI tool (JSE, 2012). The SSI tool has a broader disparity between companies in the sample, showing that, on fundamental strategy principles, some companies are communicating their embeddedness with strategic significance that can be distinguished by the SSI tool. These findings emphasise the discriminating value of the SSI tool.

- The SSI tool was found to address superfluous sustainability claims through the measurement criteria. The SSI tool measured sustainability in the context of strategising and revealed the strategising gaps arising from companies who took a compliance outlook to strategising and used marketing strategies, as opposed to communicating sustainability embeddedness in strategising.

\section{General researcher observations}

Besides the inability of the majority of companies to communicate any form of real, dedicated leadership towards sustainability, the following points were made apparent to the researchers.

It was found that most companies failed to communicate that they understood what sustainability means, both officially and in their interpretation of it applicable to their industry and corporate goals. Phrases such as 'we respect the environment' immediately suggested that the company did not have full comprehension of sustainability or the business case for it. Phrases such as these influenced the score of the final element of implementation: sustainability innovation.

Furthermore, there was a tendency for companies to label their reporting as 'integrated' although the researcher was redirected to another site with another link to access a 'lonely' sustainability report, whereas the financial reports (and other aspects of TBL sustainability) were on the main page. To ascertain the true integrated report from a 'combined' report or an 'adjacent' report, definitions were consulted.

\section{Management implications and recommendations for use of the SSI tool}

This research has investigated strategising for sustainability in the light of the gap between the challenges experienced by leadership in embedding sustainability in strategising and the rising levels of sustainability reporting and claims on communication platforms such as websites. Some commentators suggest that these claims are only surface level (Riccaboni \& Leone, 2010:130). 
The findings suggest that although some level of sustainability embeddedness was found, superfluous claims were taken into consideration to reveal strategising gaps among the leading companies' external and publicly available communication.

Smith and Sharicz (2011:76) pose the question of how it is possible for organisations to demonstrate that their sustainability declarations are not just window dressing for good looks. The researchers believe that the SSI tool addresses this challenge and supports managers in the following ways:

- Addressing strategising gaps and better-informed decision making: Knowledge of the communicated level of embeddedness in strategising affords management the opportunity to evaluate the strategising for sustainability process internally and ensure it is aligned with what is communicated. The findings afford management the chance to make informed decisions in future on strategising and on the communication to stakeholders.

- Improvement of communication strategy: Awareness of the status of one's company offers a basis for improving or redesigning the existing communication, reporting processes, marketing and corporate website design in order to project sustainability embeddedness as opposed to adhoc sustainability claims and implementation efforts.

- Company benchmarking: The Top 40 leading companies on the JSE were benchmarked on the embeddedness of strategising. The information the company was measured on was its external communication that was relayed to investors. With this information, management would be able to model a framework for the company to address the elements that the company is not achieving. Awareness of weak areas can lead to improvements to attract the socially responsible investor.

- Sustainability investing: The benchmarking quality of the SSI tool affords investors comparability and the ability to discriminate between companies to invest in. Investors who want to ascertain the sustainability embeddedness and longevity of a company's strategising can interpret the level with this SSI tool.

- Holistic sustainability measurement: The SSI tool was formulated from literature on the topic as well as an incorporation of best practice for sustainability. Measurement criteria included these, and as such, the level of sustainability embeddedness of a company that can be determined provides management with a holistic picture and measurement of sustainability in strategising.

- Quick access to information: This SSI tool can be used without internal investigation and access to restricted strategies and policies. It can be used with easily accessible, publicly available communication. It does not require confidential information. Managers who want the year-on-year results of their level of sustainability embeddedness in public communication can acquire outside skills for application of the tool without disruption of day-to-day activities.

- Discriminating quality of the SSI tool: The SSI tool contextualises sustainability within strategising and provides a level of embeddedness. This offers management the ability to determine the sustainability embeddedness level of their company in a way that is different from the current indexes and market capitalisation rankings.

\section{Suggested future research}

It is recommended that future research could address and further investigate the implementation gap between what is said and what is done. Future research should make a comparison between what was communicated publicly (the level of strategising for sustainability determined by the researcher on the SSI tool) and what is actually occurring in the JSE ALSI Top 40 Companies. A thorough internal analysis of a case company could support the making of the SSI tool and provide greater insight into the implementation gap. The research could also serve to reveal the reasons for a company's strategising for sustainability embeddedness rating by assessing how practitioners rate, rank and support the level of sustainability embeddedness in elements of strategising. Further research could seek to challenge the legitimacy of sustainability claims by determining the ground ratings for embeddedness of sustainability. 
It is also suggested that further exploration investigate the consistency between the embeddedness of sustainability in company core values, vision and mission and ascertain the correlation with implementation efforts. This would address the strategising gaps identified.

Literature and industry conversation has raised concerns regarding the alignment of implementation efforts with core business. Businesses have been found to show inconsistency between the purposes, existence and positioning of the business and implementation efforts. Further research could explore the question: Are implementation efforts in line with the core business of the company or merely fashion projects?

The present scope of research included the Top 40 Companies on the JSE ALSI ranked by market capitalisation. The research distinguished those companies who had embedded sustainability in strategising from those who held their position due to market capitalisation or who may have communicated a sustainable outlook. Further research could look at the sustainability performance or levels of embeddedness of these Top 40 companies in the context of their industries. The research could compare the strategising for sustainability performance of industry sectors to identify industry influences and highlight market leaders.

\section{LIMITATIONS OF THE STUDY}

This research employed the researchers, the measurement SSI tool and the interpretation of the English language to judge the strategising claims in sources of external communication. One researcher was positioned to interpret the information and then judge it according to a descriptive scale. In its current form, the research was therefore subject to several biases. With this type of descriptive research come the following research limitations and biases:

Researcher bias: deriving from one of the researchers being a Growthpoint employee at the time of the research. She had access to the inside happenings of the company and has adopted elements of corporate culture and loyalty. This made judging the company on the basis of external communication only and not internal knowhow a challenge.

Forced bias: the SSI tool is an interpretive model that leans heavily on the researcher's assimilation. Judgement is made according to the scale and the researcher's assessment of the communicated piece of information. In some cases a sustainability claim may be applicable to two different ratings out of 5. Of necessity, the researcher must rate the claim, which results in forced bias.

Distraction and noise interruptions when researching: A stylish and modern website that was user friendly also served as a limitation, as the researcher needed to avoid being distracted by these visual factors when ascertaining how the company had strategised for sustainability.

Unachieved scores: A company that may truly integrate sustainability into strategising but fail to create an effective communication strategy will not appear in a good light with this SSI tool (as applied to external communication), as it will not be awarded a score for embeddedness in the elements of strategising.

\section{REFERENCES:}

ACCA Association of Chartered Certified Accountants). 2011. ACCA shines spotlight on sustainability. [Online] Available from http://www.skillsportal.co.za/page/training/training companies/financial accounting training/1067340ACCA-shines-spotlight-on-sustainability [Accessed: 2011-09-10].

Adams, C.A. \& Frost, G.R. 2008. Integrating sustainability reporting into management practices. Accounting Forum, 32(4):288-302. 
Anon., 2011. Do sustainable products require sustainable leaders? Development and Learning in Organisations. 25(2):21-24.

Bonn, I. \& Fisher, J. 2011. Sustainability: the missing ingredient in strategy. Journal of Business Strategy, 32(1):5-14.

Bowers, T. 2010. From image to economic value: The genre of sustainability reporting. Corporate Communications: An International Journal, 15(3):249-262.

Capriotti, P. \& Moreno, A. 2007. Communicating corporate responsibility through corporate web sites in Spain. Corporate Communications. An International Journal, 12(3):221-237.

Carpenter, M.A. \& W.G. Sanders. 2007. Strategy management: A dynamic perspective. NJ: PrenticeHall.

Collins, E., Lawrence, S., Pavlovich, K. \& Ryan, C. 2007. Business networks and the uptake of sustainability practices: The case of New Zealand. Journal of Cleaner Production, 15(8-9):729-740.

Coupland, C. Corporate social responsibility as argument on the Web. Journal of Business Ethics, 1(62):355-366.

Cowan, D.M., Dopart, P., Ferracini, T., Sahmel, J., Merryman, K., Gaffney, S. \& Paustenbach, D.J. 2010. A cross-sectional analysis of reported corporate environmental sustainability practices. Regulatory Toxicology and Pharmacology, 58(1):524-538.

Crews, D.E. 2010. Strategies for implementing sustainability: Five leadership challenges. Advanced Management Journal, 75(2):15-21.

Dawkins, J. \& Ngujiri, 2008. Corporate responsibility: The communication challenge. Journal of Communication Challenge, 9(2):108-19.

Elmualim, A., Shockley, D., Valle, R., Ludlow, G. \& Shah, S. 2010. Barriers and commitment of facilities management profession to the sustainability agenda. Building and Environment, 45(1):58-64.

Ernst \& Young. 2011. Climate change and sustainability services and awards. [Online] Available from: http://www.ey.com/ZA/en/Services/Specialty-Services/Climate-Change-and-Sustainability-

Services/2011---ESR---Main-Page [Accessed: 2011-06-23].

Gill, D., Dickinson, S. \& Scharl, A. 2008. Communicating sustainability: A Web content analysis of North American, European and Asian firms. Journal of Communication Management, 12(3):243-262.

Guardian. 2010. Death and devastation - and it's just the start. The Guardian, 31 May. [Online] Available from: http://www.guardian.co.uk/environment/2010/may/31/bp-oil-spill-death-impact [Accessed: 2011-05-01].

Hallstedt, S., Ny, H., Robèrt, K. \& Broman, G. 2010. An approach to assessing sustainability integration in strategic decision systems for product development. Journal of Cleaner Production, 18(8):703-712.

Hillestad, T., Xie, C. \& Haugland, S.A. 2010. Innovative corporate social responsibility: The founder's role in creating trustworthy corporate brand through 'green innovation'. Journal of Product \& Brand Management, 19(6):440-451. 
Hodgkinson, G.P. \& Clarke, I. 2007. Conceptual note: Exploring the cognitive significance of organizational strategising: A dual-process framework and research agenda. Human Relations, 60(1): 243-255.

Holton, I., Glass, J. \& Price, A.D.F. 2010. Managing for sustainability: Findings from four case studies in the UK precast concrete industry. Journal of Cleaner Production, 18(1):152-160.

Idemudia, U. 2011. Corporate social responsibility and developing countries: Moving the critical CSR research agenda in Africa forward. Progress in Development Studies, 11(1): 1-18.

Ince.motiv. 2010. Audit of the 2010 Annual Review - KING III and best practice guidelines and recommendations for Growthpoint Properties. Ince.motiv.co.za, 18-23.

Integrated Reporting Definition. 2011. What is an integrated report? [Online] Available from: http://www.sustainabilitysa.org/IntegratedReporting/WhatisanIntegratedReport.aspx [Accessed: 201107-12].

JSE (Johannesburg Stock Exchange). 2011. The SRI Criteria of the JSE. [Online] Available from: http://www.jse.co.za/About-Us/SRI/Results/SRI2011Results.aspx. [Accessed: 2012-07-26].

Kane, G. 2011. The green executive: Corporate leadership in a low carbon economy. UK: Earthscan.

Klaine, A. \& Von Hauff, M, 2009. Sustainability-driven implementation of corporate social responsibility: Application of the integrative sustainability triangle. Journal of Business Ethics, 85:517533.

Lacy, P., Arnott, J. \& Lowitt, E. 2009. The challenge of integrating sustainability into talent and organisation strategies: Investigating into the knowledge, skills and attitudes to achieve high performance. Corporate Governance, 9(4): 484-494.

Laszlo, C. \& Zhexembayeva, N. 2011. Embedded sustainability: The next big competitive advantage. UK: Greenleaf.

Lee, M.J. Fairhurst, A. \& Wesley, S. 2009. Corporate Social Responsibility: A Review of the Top 100 US Retailers. Corporate Reputation Review, 12(2):140-158.

Leon-Soriana,R., Munoz-Tirress, M.J. \& Chalmeta-Rosalen, R. 2010. Methodology for sustainability strategic planning and management. Industrial Management \& Data Systems, 110(2): 249-268.

Lynch, R. 2009. Strategic Management. 5th ed. Italy: Prentice Hall.

Quinn, L. \& Dalton, M. 2009. Leading for sustainability: Implementing the tasks of leadership. Corporate Governance, 9(1):21-38.

Reilly, A.H. 2009. Communicating sustainability initiatives in corporate reports: Linking implications to organisational change. SAM Advanced Management Journal, 74(3):33-43.

Riccaboni, A. \& Leone, E.L. 2010. Implementing strategies through management control systems: A case of sustainability. International Journal of Productivity and Performance Management, 59(2):130144.

Rolland, D. \& Bazzoni, J.O. 2009. Greening corporate identity: CSR online corporate identity reporting. Corporate Communications: An International Journal, 14(3):249-263.

Searcy, C. 2009. Setting the course in corporate sustainability performance measurement. Measuring Business Excellence, 13(3):49-57. 
Setthasakko, W. 2009. Barriers to implementing corporate environmental responsibility in Thailand. International Journal of Organisational Analysis, 17(3):169-183.

Skinner, C. \& Mersham, G. 2008. Corporate social responsibility in South Africa. Society and Business Review, 3(3):239-255.

Smith, P.A.C \& Sharicz, C. 2011. The shift needed for sustainability. The Learning Organisation, 18(1):73-86.

Trendwatching, 2010. 10 crucial consumer trends of 2012. Available from: http://trendwatching.com/trends/10trends2010/ [Accessed: 2012-04-19).

UNCTAD (United Nations Conference on Trade and Development). 2011. Definition of sustainability claims. Available from: http://193.194.138.42/en/Sustainability-Claims-Portal/ [Accessed: 2011-05-21]

Uusi-Rauva, C. \& Nurkka, J. 2010. Effective internal environment-related communication: An employee perspective. Corporate Communications: An International Journal, 15(3):299-314.

Velazquez, L.E., Esquer, J., Munguia, N.E. \& Moure-Eraso, R. 2011. Sustainable learning organizations. The Learning Organization, 18(1):36-44.

White, P. 2009. Building a sustainability strategy into business. Corporate Governance, 9(4):386-394.

Yin, R.K. 2003. Case study research: Designs and methods (Applied Social Research Methods). 3rd ed. Series 5. London: Sage. 


\section{Appendix A: Example of measurement criteria for compliance element}

\section{COMPLIANCE:}

\section{INTEGRATED REPORTING}

The integrated report demonstrating integrative reporting. The report is of a high standard and demonstrates paths to ensure accountability.

1) No report visible

2) The following is visible:

- A policy to address sustainability or a sustainability report that acknowledges sustainability

- A document that is separate from the financial and other reports such as the annual report and not easy to find

- An indication that the sustainability document is secondary in priority to other reports.

3) A visible report demonstrates:

- Compliance with one voluntary standard or guidance criteria such as: GRI/JSE SRI/ISO 2600

- Phrases such as: 'we are on a journey to KING III' or 'KING III suggests integrative reporting' and indication of their intention to comply in the near future.

- More than just an acknowledgement of sustainability. They are showing an effort to disclose information, yet the language is leaning towards CSR rather than Sustainability.

- A level of integration with other reports but remains disjointed on the website from other primary communication e.g. financials

- An indication that the company has produced a combined report.

- That it has been made somewhat accessible to users on the organisation's website

4) The report is

- Made very accessible to users on the organisation's website

- Comprehensive in nature, and described as an integrated report, but sustainability is still primarily addressed on a separate page/another link

- Not scarce on details on disclosure and represents more than mere compliance

- Indicative that the company has used numerous voluntary standards eg: GRI Standards or attempted to align their reporting with one, or with the UN Global Compact, JSE SRI Index, and ISO 2600 sustainability reporting and performance frameworks

5) A comprehensive report is

- Fully integrated with the other reports, i.e. an integrated report demonstrating integrative reporting (verb)

- Communicates a balance between TBL elements.

- Able to demonstrate through the use of strategic language that the company is not merely complying with sustainability but it is embedded.

- Refers to both disclosure and performance of sustainability.

- Of a high standard (impressive and value adding) and makes reference to using the GRI framework, including the GRI Index, or the UN Global Compact, JSE SRI Index, and ISO 2600 sustainability reporting and performance frameworks.

- Supported by evidence of accountability, such as internal and external assurance processes.

Due to space limitations. The authors can be contacted for the full use and application of the evaluation instrument. 